\title{
DECENTRALIZED PRICING MANAGEMENT IN HOUSING AND MUNICIPAL ECONOMY
}

\author{
Horoshkova L. A., \\ Volkov V. P., \\ Khlobystov le. V.
}

Actuality of research theme. The process of Ukraine's integration into the European Community actualizes the issue of the compliance of the administrative and territorial structure with European principles of regional and local development organization, and the formation of local self-government. Nowadays the problem of developing an effective system of management of the infrastructure united territorial communities (UTCs) formation in the context of administrative and territorial reform implementation based on the principles of decentralization becomes especially acute.

Problem statement. Nowadays conditions, the reform of the administrative-territorial structure and the decentralization of power in Ukraine require special attention to the problem of housing and communal services management, since its maintenance is ensured by local authorities and created in the process of reforming the united territorial communities (OTCs).

Analysis of the last researches and publications. The modern aspects of decision of problems of development of territorial communities and local self-government such scientists engage in, as Pavliuk A. P., Oliinyk D. I., Batalov O. A., Datsko O. I., Murkovych L. L., Molodozhen Yu. B.and other [1-4]. The results of own researches of problem are in to [5-13].

Selection of unexplored parts of general issue. The new administrative and territorial system should become the basis for constructing a new model of territorial administration, based on the principles of decentralization, subsidiarity, balance of national interests with regional and territorial communities' interests representation, local self-governance widespread, territorial communities 'power and autonomy, coherence with natural geographical capacity. That is why the problem of mechanism for managing regional housing and communal services programs and to determine the optimal pricing models taking into account world experience

Task statement, research aim. To search for new mechanisms of efficient pricing management in housing and utilities using world experience and peculiarities of domestic business practices

Method or methodology of realization of research. In the process of realization researches drawn on scientific (analysis and synthesis, induction and deduction, analytical grouping) and special (abstracting, economicalmathematical design, etc.) methods of study of the economic phenomena and processes.

Exposition of basic material (job performances). In the world practice certain methods of pricing under natural monopoly were formed. The analysis of the essence and peculiarities of these methods to adopt the best practices:

a) Rate of return regulation. This is the most traditional approach to set price of goods (services) of natural monopolies. It is based on cost-plus pricing calculation. It is used in Ukraine.

b) Price cap regulation (price restrictions). The method's essence is to set fixed maximum price limitations by the regulatory institution. The institution has the right to set the price, which is lower or equals the limit, and to profit. As the profit does not correlate to costs, there is the stimulating mechanism to cut them. The model assumes quite a long period between tariff revisions - 4-5 years.

c) Profit-sharing plan with sliding scale. Unlike the previous method, in which natural monopoly gains significant profits, this method assumes to use the sliding scale of profit distribution between a producer and a consumer.

d) Price discrimination. Price discrimination is a pricing strategy that charges customers or their groups' different prices for the same product or service. Price difference does not depend on production costs or supply costs. Price discrimination is possible if consumers 'direct price elasticity of demand is different.

Conclusions. The analysis of the natural monopoly's world pricing practice, including national housing and utilities sector has been carried out. It has been stated that the main methods of monopolistic pricing are: rate of return regulation; price cap regulation (price restrictions); profit-sharing plan with sliding scale; price discrimination; multi-rate tariffs; pricing for different competition forms, compatible with natural monopoly.

The obtained findings prove the necessity of modification to the housing and utilities sector's monopoly market by implementation of competition elements.

Keywords: territorial society, housing-municipal services, price formation, monopoly, competition

JEL Classification: C53, H79, O10, R15

\section{ДЕЦЕНТРАЛІЗОВАНЕ УПРАВЛІННЯ ЦІНОУТВОРЕННЯ У ЖИТЛОВО-КОМУНАЛЬНОМУ ГОСПОДАРСТВІ}

Горошкова Л. А., Волков В. П., Хлобистов Є. В.

Актуальність теми дослідження. Процес інтегрування України до Європейського Співтовариства актуалізує питання відповідності адміністративно-територіального устрою європейським принципам організації управління регіональним і місцевим розвитком, розбудови місцевого самоврядування. У сучасних умовах реалізації адміністративно-територіальної реформи на засадах децентралізації, 
особливої актуальності набуває проблема формування ефективної системи управління інфрраструктурою об'єднаних територіальних громад.

Постановка проблеми. В сучасних умовах реформування адміністративно-територіального устрою та децентралізації влади в Україні потребують особливої уваги проблеми управління житловокомунальним господарством, оскільки його утримання забезпечують місцеві органи державної влади та створені у процесі рефоормування об'єднані територіальні громади (ОТГ).

Аналіз останніх досліджень і публікацій. Сучасними аспектами вирішення проблем розвитку територіальних громад та місцевого самоврядування займаються такі вчені, як Павлюк А. П., Олійник Д. І., Баталов О. А., Дацко О. І., Муркович Л. Л., Молодожен Ю. Б. та ін. [1-4]. Результати власних досліджень проблеми наведені в [5-13].

Виділення недосліджених частин загальної проблеми. Новий адміністративно-територіальний устрій має стати основою побудови нової моделі територіального управління, заснованої на засадах децентралізації, субсидіарності, балансу загальнонаціональних інтересів з інтересами населення регіонів та територіальних громад, повсюдності місцевого самоврядування, спроможності та самостійності територіальних громад, узгодженості з природно-географрічним потенціалом. Саме тому на особливу увагу заслуговує проблема управління формування механізму управління регіональними програмами житлово-комунального господарства та визначення оптимальних моделей ціноутворення з урахуванням світового досвіду.

Постановка завдання, мети дослідження. Здійснити пошук нових механізмів ефрективного управління ціноутворення у житлово-комунальному господарстві з використанням світового досвіду та особливостей вітчизняної практики господарювання.

Метод або методологія проведення дослідження. У процесі проведення дослідження використані загальнонаукові (аналіз та синтез, індукція та дедукція, аналітичне групування) та спеціальні (абстрагування, економіко-математичне моделювання і т. ін.) методи вивчення економічних явищ і процесів.

Викладення основного матеріалу (результати роботи). Світова практика ціноутворення у природних монополіях сфрормувала певні методи. Проаналізовані сутність та особливості цих методів з метою запозичень їх позитивного досвіду:

а) Регулювання норми прибутку. Це найбільш традиційний підхід до встановлення цін на товари (послуги) природних монополій. В його основу покладено калькулювання за принципом «витрати плюс випуск». Він використовується і в Україні.

б) Регулювання верхньої межі тарифру (цінове лімітування). Сутність метода полягає у встановленні фріксованих максимальних цінових лімітів, що встановлюється регулюючою фрірмою. Фірмі дозволено визначати ціну меншу, або таку, що дорівнює ліміту та привласнювати отриманий прибуток. Унаслідок того, що прибуток фрірми не залежить від витрат, виникає стимулюючий механізм щодо їх скорочення. Модель передбачає досить тривалий проміжок часу між переглядом тарифрів - 4-5 років.

в) Схема участі у прибутку із рухомою (ковзкою) шкалою. На відміну від попереднього метода, за якого природна монополія може отримувати суттєві прибутки, цей метод передбачає, що використовується ковзка шкала розподілу прибутку між виробником та споживачем.

г) Цінова дискримінація. Цінова дискримінація - практика за якої ціни на одні й ті ж блага для різних покупців або їх груп, встановлюються різні. При цьому розбіжності в ціні не залежать від витрат на виробництво та доставку блага. Цінова дискримінація можлива, якщо пряма еластичність попиту на товар за ціною у різних споживачів $є$ різною. Необхідною умовою проведення цінової дискримінації $є$ неможливість перепродажу товару, тому саме у сфрері послуг вона отримала найбільше розповсюдження.

Висновки. Проведено аналіз світової практики ціноутворення у природних монополіях, до числа яких належить вітчизняне ЖКГ. Встановлено, що основними методами монопольного ціноутворення $є$ : регулювання норми прибутку; регулювання верхньої межі тарифу (цінове лімітування); схема участі у прибутку із ковзкою шкалою; цінова дискримінація; багатоставочні тарифи; ціноутворення за різними формами конкуренції, що сумісні із природною монополією.

Отримані результати свідчать про необхідність модифрікації монопольного ринку житловокомунальних послуг введенням елементів конкуренції.

Ключові слова: територіальна громада, житлово-комунальне господарство, ціноутворення, монополія, конкуренція

\section{ДЕЦЕНТРАЛИЗОВАННОЕ УПРАВЛЕНИЕ ЦЕНООБРАЗОВАНИЕМ В ЖИЛИЩНО-КОММУНАЛЬНОМ ХОЗЯЙСТВЕ}

Горошкова Л. А., Волков В. П., Хлобыстов Е. В.

Актуальность темы исследование. Процесс интегрирования Украины в Европейское Сообщество актуализирует вопрос соответствия административно-территориального устройства европейским принципам организации управления региональным и местным развитием, развития местного самоуправления. В современных условиях реализации административно-территориальной 
реформы на основах децентрализации, особой актуальности приобретает проблема формирования эфффективной системы управление инфраструктурой объединенных территориальных общин.

Постановка проблемы. В современных условиях реформирования административно-территориального устройства и децентрализации власти в Украине требуют особого внимания проблемы управление жилищнокоммунальным хозяйством, поскольку его содержание обеспечивают местные органы государственной власти и созданные в процессе реформирования объединенные территориальные общины (ОTO).

Анализ последних исследований и публикаций. Современными аспектами решения проблем развития территориальных общин и местного самоуправления занимаются такие ученые, как Павлюк А. П., Олейник Д. И., Баталов О. А., Дацко О. И., Муркович Л. Л., Молодожен Ю. Б. и др. [1-4]. Результаты собственных исследований проблемы приведенные в [5-13].

Выделение неисследованных частей общей проблемы. Новое административно-территориальное устройство может стать основанием построения новой модели территориального управления, основанной на основах децентрализации, субсидиарности, баланса общенациональных интересов с интересами населения регионов и территориальных общин, повсюдности местного самоуправления, возможности и самостоятельности территориальных общин, согласованности с природногеографическим потенциалом. Именно поэтому особого внимания заслуживает проблема управления формирование механизма управление региональными программами жилищно-коммунального хозяйства и определение оптимальных моделей ценообразование с учетом мирового опыта.

Постановка задачи, цели исследования. Осуществить поиск новых механизмов эффрективного управления ценообразования в жилищно-коммунальном хозяйстве с использованием мирового опыта и особенностей отечественной практики хозяйствования.

Метод или методология проведения исследование. В процессе проведения исследование использованные общенаучные (анализ и синтез, индукция и дедукция, аналитическое группирование) и специальные (абстрагирование, экономико-математическое моделирование и др.) метод изучение экономических явлений и процессов.

Изложение основного материала (результаты работы). Мировая практика ценообразования в естественных монополиях сфрормировала определенные методы. Проанализированы сущность и особенности этих методов с целью заимствований их положительного опыта:

а) Регулирование нормы прибыли. Этот наиболее традиционный подход к установлению цен на товары (услуги) естественных монополий. В его основу положены калькулирование по принципу «затраты плюс выпуск». Он используется и в Украине.

б) Регулирование верхней границы тарифа (ценовое лимитирование). Сущность метода состоит в установлении фоксированных максимальных ценовых лимитов, который устанавливается регулирующей фрирмой. Фирме разрешено определять цену меньшую, или такую, что равняется лимиту и присваивать полученную прибыль. Вследствие того, что прибыль фирмы не зависит от затрат, возникает стимулирующий механизм относительно их сокращения. Модель предусматривает довольно продолжительный промежуток времени между просмотром тарифов - 4-5 лет.

в) Схема участия в прибыли с подвижной (скользящей) шкалой. В отличие от предшествующего метода, при котором естественная монополия может получать существенные прибыли, этот метод предусматривает, что используется скользящая шкала распределения прибыли между производителем и потребителем.

г) Ценовая дискриминация. Ценовая дискриминация - практика при которой цены на одни и те же блага для разных покупателей или их групп, устанавливаются разные. При этом расхождения в цене не зависят от затрат на производство и доставку блага. Ценовая дискриминация возможная, если прямая эластичность спроса на товар по цене у разных потребителей есть разной. Необходимым условием проведения ценовой дискриминации есть невозможность перепродажи товара, поэтому именно в сорере услуг она получила наибольшее распространение.

Выводы. Проведен анализ мировой практики ценообразования в естественных монополиях, к числу которых належит отечественное ЖКГ. Установлено, что основными методами монопольного ценообразования есть: регулирование нормы прибыли; регулирование верхней границы тарифра (ценовое лимитирование); схема участия в прибыли с скользкой шкалой; ценовая дискриминация; многоставочные тарифы; ценообразование за разными фрормами конкуренции, которые совместные с естественной монополией.

Полученные результаты свидетельствуют о необходимости модификации монопольного рынка жилищно-коммунальных услуг введениям элементов конкуренции.

Ключевые слова: территориальная община, жилищно-коммунальное хозяйство, ценообразование, монополия, конкуренция

Actuality of research theme. The process of Ukraine's integration into the European Community actualizes the issue of the compliance of the administrative and territorial structure with European principles of regional and local development organization, and the formation of local self-government. Nowadays the problem of developing an effective system of management of the infrastructure united territorial communities (UTCs) formation in the context of administrative and territorial reform implementation based on the principles of decentralization becomes especially acute. 
Problem statement. Nowadays conditions, the reform of the administrative-territorial structure and the decentralization of power in Ukraine require special attention to the problem of housing and communal services management, since its maintenance is ensured by local authorities and created in the process of reforming the united territorial communities (OTCs).

Analysis of the last researches and publications. The modern aspects of decision of problems of development of territorial communities and local self-government such scientists engage in, as Pavliuk A.P., Oliinyk D.I., Batalov O.A., Datsko O.I., Murkovych L. L., Molodozhen Yu.B.and other [1-4]. The results of own researches of problem are in to [5-13].

Selection of unexplored parts of general issue. The new administrative and territorial system should become the basis for constructing a new model of territorial administration, based on the principles of decentralization, subsidiarity, balance of national interests with regional and territorial communities' interests representation, local self-governance widespread, territorial communities` power and autonomy, coherence with natural geographical capacity. That is why the problem of mechanism for managing regional housing and communal services programs and to determine the optimal pricing models taking into account world experience

Task statement, research aim. Searching a new mechanisms of efficient pricing management in housing and utilities using world experience and peculiarities of domestic business practices.

Method or methodology of realization of research. In the process of realization researches drawn on scientific (analysis and synthesis, induction and deduction, analytical grouping) and special (abstracting, economicalmathematical design, etc.) methods of study of the economic phenomena and processes.

Exposition of basic material (job performances). A territorial community can be considered a regional natural monopoly, since it has the exclusive right to own scarce resources - land and other movable and immovable property, which are in communal ownership and managed by a community.

In the world practice certain methods of pricing under natural monopoly were formed. Let us study the essence and peculiarities of these methods to adopt the best practices:

a) Rate of return regulation. This is the most traditional approach to set price of goods (services) of natural monopolies. It is based on cost-plus pricing calculation. It is used in Ukraine.

b) Price cap regulation (price restrictions). The method`s essence is to set fixed maximum price limitations by the regulatory institution. The institution has the right to set the price, which is lower or equals the limit, and to profit. As the profit does not correlate to costs, there is the stimulating mechanism to cut them. The model assumes quite a long period between tariff revisions - 4-5 years.

c) Profit-sharing plan with sliding scale. Unlike the previous method, in which natural monopoly gains significant profits, this method assumes to use the sliding scale of profit distribution between a producer and a consumer.

d) Price discrimination. Price discrimination is a pricing strategy that charges customers or their groups' different prices for the same product or service. Price difference does not depend on production costs or supply costs. Price discrimination is possible if consumers' direct price elasticity of demand is different.

Precondition of price discrimination is lack of possibility of resale of product, so it is widely spread in service sector.

There are three degrees of price discrimination: first, second, third.

In discrimination of the first degree, the monopolist knows the maximum amount of money each consumer can pay for any quantity of products and fixes up prices accordingly. However, this situation, in our opinion, is perfect. It is possible to implement this pricing mechanism within, for example, a small city, but within the country as a whole, it is a difficult task.

In discrimination of the second degree, the monopolist sells in blocks of units at different prices. In actual practice it mostly refers to discount pricing

According to a well known rule of $\mathrm{H}$. von Stackelberg [14] the marginal revenue of selling any blocks of units except of the last $(M R)$ must equal the price of the next block of units $(P)$, and the marginal revenue of selling of the last block of units must equal marginal costs $(M C): M R 1=P 2, M R 2=P 3, \ldots . M R n=M C$.

In discrimination of this degree prices are set both as decreasing function of sales $(P 1>P 2>P 3, Q 1<Q 2<$ Q3), and increasing function $(P 1<P 2<P 3, Q 1<Q 2<Q 3)$.

Price discrimination of the second degree is often represented by the discount system, but there are opposite cases.

Third degree price discrimination refers to the fact that the market demand is divided into some segments with different functions of demand. The monopolist charges different price to each class of customer to gain the maximum possible total profit. The preconditions to its implementation exist if the consumers of a certain product may be divided according to the price elasticity of demand. In this case, the sectoral demand is illustrated by a few demand curves. Then total revenue from selling products in different $n$ segments charging different prices becomes:

$$
\pi=P 1 Q 1+P 2 Q 2+\ldots+P n Q n-T C(Q) .
$$

The condition for profit maximizing is: $M R 1=M R 2=\ldots=M R n=M C$.

Thus, the price charged in every segment must satisfy the equality of all segments equal marginal revenue and marginal costs of the total output.

e) Multi-rate tariffs. The advantages of correctly designed multi-rate tariffs are higher aggregate surplus in comparison with single rate. In the world practice multi-rate tariffs differentiated by purchase and time of goods (services) purchase are applied. The most simple is the two-part tariff pricing policy (two stage payment) whereas a consumer pays for the right to buy a product (access to a product), then (after the purchase) additionally pays for the consumption of every unit.

f) Pricing for different competition forms, compatible with natural monopoly. Unlike the approach of the state burden in the monopoly regulation, it is possible to use the following models of competition: 
- Contestable markets` competition;

- Competition «for» market;

- Yardstick competition.

W. Baumol, J. Panzar, and R. Willig are the authors of the contestable markets' competition model [15-17]. To enhance natural monopolies performance efficiency they propose to ensure free market enter and exit. In our opinion it is difficult to implement the model in housing and utilities sector, as most of its subsectors are closely related to cost intensive systems; this will hinder price liberalization.

H. Demsetz, J. Stigler and R. Posner formed the concept of competition «for» market in 1960-70th of the XX century $[18,19]$. In this case, if the internal competition is impossible because of substantial economy of scale, it is necessary to stimulate it. In this situation, the regulatory institution conducts an auction. The company which bid the higher price gets the right to operate in the market for a certain period of time. If this regulation takes place, the more competitors operate in the market, the greater budget revenues are.

Thus, this concept's competition is focused in the auction. At the termination of the contract, a new auction is announced, which stimulates the winning company to improve its performance and create the appropriate image.

Therefore, the state in this case does not provide services. It delegates the right to a private-owned company; create conditions for public-private partnership.

Let us analyze foreign experience of these tools applying in housing and utilities sector.

a) Rate of return regulation. The mentioned method is used in the USA to determine electricity tariffs. First, the rate base is calculated. It measures the volume of capital used by the company to carry on a regulated activity. Then «reasonable and fair» capital rate of return is set. Rate of return equals the value of the attracted capital (its alternative costs). The regulation institution imposes so-called «reasonable rate of return». It is set at a rate of competitive industries' rate of return, which have very close level of economic risks.

Capital structural elements allowed to include into the monopolist's rate base must be accepted by the regulation institution as «used and useful». For instance, in the USA this base does not include facilities that have not been completed more than by $3 \%$.

In national practice, the «need in profit» is determined as the sum of profit enough to make planned capital investments, tax payments, etc. Hence, when pricing housing and utilities services, there is a significant difference between the world practice (the products` (services`) price embodies the cost of attracting operating capital (interest on capital)) and national practice (the total amount of future investment). In the USA regulation institutions decide the list of expenditures allowed to include in services ' costs of natural monopolies.

In the U.S. electric-power industry, for example, only about one third of the investment is accumulated at the expense of internal sources (depreciation and undistributed profits). Two-thirds of the projects are funded from external sources (mainly at the expense of attracted capital and share issue).

To make the activity of natural monopolies really efficient, so there would be no intentions to overstate expenditures, the strict control of their maintenance and capital expenditures is performed.

There are the following disadvantages of this method:

1) lack of stimulating mechanism of efficiency growth. Pricing is cost-based (on the basis of the actual expenditures). It stimulates shifting expenditures to consumers.

2) the complexity of the actual activity regulation because of subjective assessments in determining the rate of return and tariffs.

b) Price cap regulation (price restrictions). This methods began to be actively used in the second half of 1980 $s$ in the UK after some natural monopolies privatization, for instance, «British Telecom» (1984) and «British gas» (1986). The system of regulation was extended to water supply in $1989-1990$ and to electric-power industry starting from 1990. The implementation mechanism was the next: Regional departments of the Electricity Regulatory Office coordinated and approved tariffs for communal domestic consumers based on the principle of price restrictions, for other consumer groups and the wholesale market prices remained marketable. By the end of 1980-s the practice extended to the USA, New Zealand, Malaysia, Mexico, Peru, Argentina.

Let us study more precisely the procedure of price cap assessment.

Price restrictions are determined by the prior set exogenous correcting company's indicator. This indicator is most often the consumer price index $(R P I)$ minus productivity factor $(X), \%$. Thus the base price for the next period $(P i+1)$ is determined by the formula:

$$
P i+1=P i(R P I-X)
$$

where $\mathrm{Pi}$ - base price of the previous period, UAH per unit; $R P I$ - consumer price index, $\%$; $X$ - productivity factor, \%.

The mechanism is called $R P I-X$-regulation. The value of $X$ is determined by estimations of expected demand, volumes of investments, unregulated revenues, the probability of cutting costs and productivity growth, investment needs.

In the US GNP deflator is used as a corrective indicator.

One of this model's advantages is its lower cost-based characteristic and so higher efficiency. As producers get guaranteed profitability between the adjustments of $X$ values, a natural monopoly acts under incentive to improve its efficiency. As a result, consumers will be able to have lower services prices.

This method's effectiveness was illustrated by the Great Britain during 1992 - 1997 after public sector companies ' privatization. During the period, electric-power sector expenditures were cut by $17 \%$, employment - by 
$26 \%$. In 1992 in gas industry consumer prices were reduced by $14 \%$ (it is more than the level of wholesale gas prices contraction in the country during the same period). The positive consequence was $28 \%$ average return on investment in utility companies in gas, water and electricity industries in the stock market.

Nevertheless, the mentioned method has some flaws, like:

1) RPI - X - method breaks the investment schedule. An enterprise is interested to cut expenditures in the beginning of the regulation period as it gets the amount of expenses saved, but in the end of the period the incentives to increase efficiency disappear;

2) Possibility of price variations to raise company`s profits. If it simultaneously does not lead to deterioration of consumers' welfare, it increases the welfare level in society. The negative consequence is the redistribution of social tensions, because, as a rule, there is price increase for small consumers and a decrease for large ones;

3 ) It is necessary to provide certain conditions, i.e. informational, to assess $X$ value. Probabilistic causation of $X$ factors reduces the accuracy of the corrective indicator's definition;

4) The method does not provide the possibility to stimulate certain quality level of services and the necessity to increase it;

c) Profit-sharing plan with sliding scale. The mentioned plan is successfully used in the energy industry of Indiana (USA). A sliding scale is used there. A company earns profit with $10,6 \%$ rate of return. Consumers ' earnings are $12,3 \%$. The profit volume between these two values is distributed between a company and consumers.

d) Price discrimination. In our concern, it is possible to provide traditional strategies of pricing in housing and utilities sector, but taking into consideration industry`s specifics. It has to be considered, that the process of price discrimination used by natural monopolies is complicated to control, as monopoly`s cost functions are unknown.

Let us analyze Colombia experience in electricity supply. The highest prices are set for those who consume the biggest amount of energy. The goal of such pricing is to distribute profit for the sake of the poorest segments of the population. The utilities prices may be the tool of revenues distribution.

In the Republic of Belarus from October 1st, 2011 a differential tariffs for water and wastewater services were introduced, depending on volumes of consumption. From February 1st, 2013, the mechanism of differential tariffs for electricity and gas supply were introduced.

The similar pricing practice of electricity consumption charging exists in Ukraine.

Price discrimination by time may be applied in housing and utilities sector (different charges for the consumed services in case of their advance payment, timely payment or delay in payment).

A large share of population in Ukraine needs financial assistance to charge utility bills, therefore, in our opinion, the unlimited shift of tariffs burden on manufacturing does not make economic sense. In such a situation, the need for the state financial aid arises again.

e) Multi-rate tariffs. Colombia has the experience of multi-rate tariffs application too. In the state of Medellin there was the system of time rates for the consumed electricity by households based on the multi-rate tariffs. National statistical agency divided all the buildings into six categories with different characteristics and housing quality. They worked out multi-rate tariffs for every category, which included:

1) Fixed enter costs (monthly installment for connection to the grid), which did not depend on the volume of electricity consumption;

2) Five tariff rates (which grew depending on the volume of electricity consumption).

France has an interesting experience of multi-rate tariffs with time differentiation. In 1982-1986s, a new system of electricity tariffs was introduced in France. It was different from the previous one in wide differentiation by categories: by season; time of day; types of consumers; network load density, etc. It turned out that the new tariffs stimulate a decrease in consumers 'load during the winter maximum load because of preferential tariffs charging during another period of the year. The difference in rates was impressive - electricity during the peak loads cost almost 20 times higher than the base summer price. Besides, the grid connection fee differentiated depending on the season - in winter it was 2 times higher than in summer. In general, France has the lowest in Europe cost of electricity (kWh ) thanks to this system.

Let us analyze the experience of Belgium as for multi-rate tariffs. The company proposed the following tariff: connection charge was similar to all entities - $240 \mathrm{~b}$.fr. If consumption was $450 \mathrm{kWh}$ the tariff was $5.75 \mathrm{~b}$. fr., if consumption was from $450 \mathrm{kWh}$ to $720 \mathrm{kWh}$, the tariff was $3.10 \mathrm{~b}$. fr., if consumption was more than $720 \mathrm{kWh}$ the tariff was $2.02 \mathrm{~b}$. fr. The trade union offered to replace this tariff by the increasing one, but the regulating institution proposed another option:

1) Public tariff: connection fee -200 b. fr.per year; usage charge $-4,8$ b. fr. for $1 \mathrm{kWh}$.

2) Normal tariff: connection fee $-1300 \mathrm{~b}$. fr.; usage charge $-2,7 \mathrm{~b}$. fr. for $1 \mathrm{kWh}$.

Public tariff was used as a rule by consumers with low volume of consumption - to $600 \mathrm{kWh}$. Thus, the regulation institution implemented the mechanism of price discrimination, i.e. additional consumers surplus is removed from wealthier population.

The advantage of multi-rate tariffs lies in the fact that depending on situation regulation authorities may choose the optimization criterion of the multi-rate tariff. It may be:

1) Consumer`s surplus maximization, if the monopoly satisfies the break-even constraint;

2) Monopoly profit maximization in case of Pareto-improved status of all market players;

3) Total surplus maximization, if the monopoly satisfies the break-even constraint and in case of Paretoimproved status of all market players. 
The simplest non linear tariff is the two-part tariff consisted of connection charge and $\mathrm{P}$ rate (marginal price) per unit. Coase was the first to propose it [14].

Practice of multi-rate (non-linear) tariffs application in various countries showed their high efficiency in comparison with single-rate (linear) tariffs. Moreover, the shift from linear price set at the level of average total costs to non-linear pricing based on the multi-rate tariffs with decreasing rates for the growing consumption, stimulates demand for goods (services). This leads to the improvement of Pareto-status of the most of consumers

In our opinion, multi-tariff tariffs system is interesting as for its implementation in the housing and utilities sector of Ukraine. In the condition of Ukrainian housing and utilities sector's state and the possibility of its fixed assets renewal, this type of pricing policy opens up certain opportunities.

Current tariffs in Ukraine do not encompass the investment part.

The introduction of two-part tariffs would make it possible for the housing and utilities sector, at the expense of a fixed part charged for services by the entire population, regardless of the volume of services consumption, to renew the fixed assets of the industry.

f) Pricing for different competition forms, compatible with natural monopoly. We consider that similar practice can be successfully used in Ukraine.

The mentioned concept has some disadvantages. It should be noted that a long-term contract, which fixes the price, could both allow a firm to earn excess profits and lead to bankruptcy. At the same time, short-term contracts cause obstacles to investing. In addition, costs`cut down can lead service quality deterioration.

Yardstick competition is the weakest form of competition. It is based on comparison of this company with its counterparts in terms of its performance efficiency. England has positive experience of its implementation. Thus, because of water and energy systems privatization, regional monopolies were created. This made it possible to compare the results of firms ' performance that managed water and energy supply.

Hence, according to the study results, unsatisfactory technical condition and risk of Ukrainian housing and utilities sector's infrastructure, the uncertainty of legal and financial status require depth separate research.

Conclusion. The analysis of the natural monopoly`s world pricing practice, including national housing and utilities sector has been carried out. It has been stated that the main methods of monopolistic pricing are: rate of return regulation; price cap regulation (price restrictions); profit-sharing plan with sliding scale; price discrimination; multi-rate tariffs; pricing for different competition forms, compatible with natural monopoly.

The obtained findings prove the necessity of modification to the housing and utilities sector's monopoly market by implementation of competition elements.

\section{References}

1. Batanov, O. V. (2008). Terytorialna hromada - pervynnyi subiekt munitsypalnoi vlady v Ukraini: poniattia ta oznaky [A territorial community - primary subject of municipal authority in Ukraine: concept and attribute]. URL: http://www.cvk.gov.ua/visnyk/pdf/2008_2/visnik_st_13.pdf. [in Ukr.].

2. Molodozhen, Y. B. (2006). Poniattia i sutnist terytorialnoi hromady v systemi mistsevoho samovriaduvannia Ukrainy [Concept and essence of a territorial community in system of local self-management of Ukraine]. University scientific slip: a magazine of Khmelnitskiy university, 2. 128-136. [in Ukr.].

3. Murkovich, L. A. (2010). Terytorialna hromada yak subiekt mistsevoho samovriaduvannia v Ukraini: teoretychni aspekty [Territorial community as the subject of local self-management in Ukraine: theoretical aspects]. URL: http://www.dbuapa.dp.ua/vidavnictvo/2010/2010_02\%285\%29/10mliuta.pdf. [in Ukr.].

4. Terytorialna hromada yak bazova lanka administratyvno-terytorialnoho ustroiu Ukrainy: problemy ta perspektyvy reformuvannia [Territorial community as a base part of the administrative - territorial device of Ukraine: problems and prospects of reforming. The analytical report]. Kyiv: NISI, 2016. 61 p. [in Ukr.].

5. Volkov, V. P., Horoshkova, L. A., Karbivnychyi, I. O. (2018). Naukovi zasady tekhnolohii upravlinnia resursamy komunalnoi vlasnosti $v$ umovakh reformuvannia [Scientific principles of technologies of management of community property resources are in the conditions of reformation]. Belostok: Belostok, $138 \mathrm{p}$.

6. Horoshkova, L., Volkov, V., Kapranova, L., Komelina, A. (2018). The Reverse Subsidy`s Impact of United Territorial Community`s Budget Generations. International Journal of Engineering \& Technology, 7(4.8). 539-543.

7. Volkov, V. P., Karbivnychyi, I. O., Karbivnychyi, R. O., Horbova, I. A. (2018). Conditions of the no-loss functioning of territorial formation. Belostok: Belostok, $190 p$.

8. Volkov, V. P., Horoshkova, L. A., Karbivnychyi, R. O. (2018). Upravlinnia nerukhomistiu terytorialnykh hromad. Belostok: Belostok, 144 p. [in Ukr.].

9. Horoshkova, L. A., Volkov, V. P. (2018). Upravlinnia finansovymy protsesamy detsentralizatsii ta formuvannia terytorialnykh hromad [Management of decentralization and forming of territorial communities financial processes]. University Economic Bulletin, 36/1. 285-293. [in Ukr.].

10. Horoshkova, L. A., Volkov, V. P., Karbivnychyi, R. O. (2018). Rol mizhbiudzhetnoho rehuliuvannia u finansovii spromozhnosti terytorialnykh hromad [A role of the interbudgetary adjusting is in financial possibility of territorial communities]. Bulletin of Priazovsky Technical University. Series: Economic sciences, 36. 5-12. [in Ukr.].

11. Husieva, I. I., Seheda, I. V., Khlobystov, Ye. V. (2015). Ekolohizatsiia enerhetyky u zabezpechenni staloho rozvytku derzhavy [Greening energy in ensuring sustainable development of the state] NTUU "KPI», ITHIP NANU, The University of Economics and Humanities. Kyiv-Bielsko-Biala: vydavets Chabanenko Yu.A. 276 s. [in Ukr.]. 
12. Derzhavna ekolohichna polityka Ukrainy v umovakh detsentralizatsii vlady [A public ecological policy of Ukraine is in the conditions of decentralization of power] / nauk. red. d.e.n., prof. Ye. V. Khlobystova. Kyiv, 2016.226 p. [in Ukr.].

13. Khlobystov, Ye. V. (2016). Osoblyvosti formuvannia ta rozvytku mizhnarodnoi ekolohichnoi polityky Ukrainy za umov detsentralizatsii vriaduvannia [State environmental policy of Ukraine in conditions of decentralization of power] Kyiv: DU IEPSR NAN Ukrainy, 226 p. [in Ukr.].

14. Microeconomics (2007). Edited by V. D. Bazylevich. K. : Znannia, 2007. 677 p.

15. Baumol, W., Panzar, J., Willig R. (1982). Contestable markets and theory of industry structure. New York: Harcourt Brace Jovanovich. 510 p.

16. Baumol, W. (1977). On the proper tests for natural monopoly in a multiproduct industry. American Economics Review, 7. 809-822.

17. Panzar, J., Willig, R. (1977). Free entry and the sustainability of nftural monopoly. Bell Journal of Economics, 8. 1-22.

18. Galperin, V. M., Ignatiev, S. M., Morgunov, V. I. (1998). Microeconomics. Vol. 1, 2. S-Pb. : The School of Economics. $503 p$.

19. Demsetz, H. (1964). The Exchange and Enforcement of Property Rights. Journal of Law and Economics, 7. $11-26$

\section{ДАНІ ПРО АВТОРІВ}

Горошкова Лідія Анатоліївна, д.е.н., доцент, академік Академії економічних наук України, професор кафедри підприємництва, менеджменту організацій та логістики Запорізького національного університету,

e-mail: goroshkova69@gmail.com

Волков Володимир Петрович, д.т.н., професор, академік Академії економічних наук України, професор кафедри підприємництва, менеджменту організацій та логістики Запорізького національного університету,

e-mail: volkovvp49@gmail.com

Хлобистов Євген Володимирович, д.е.н., професор, академік Академії економічних наук України, професор кафедри екології Національного університету «Києво-Могилянська академія», вул. Григорія Сковороди, 2, Київ 04655, Україна

e-mail: ievgen.khlobystov@ukr.net

\section{ДАННЫЕ ОБ АВТОРАХ}

Горошкова Лидия Анатольевна, д.э.н., доцент, академик Академии экономических наук Украины, профессор кафедры предпринимательства, менеджмента организаций и логистики Запорожского национального университета,

e-mail: goroshkova69@gmail.com

Волков Владимир Петрович, д.т.н., профессор, академик Академии экономических наук Украины, профессор кафедры предпринимательства, менеджмента организаций и логистики Запорожского национального университета,

e-mail: volkovvp49@gmail.com

Хлобыстов Евгений Владимирович, д.э.н., професор, академик Академии экономических наук Украины, профессор кафедры экологии Национального университета «Киево-Могилянская академия» e-mail: ievgen.khlobystov@ukr.net

\section{DATA ABOUT THE AUTHORS}

Horoshkova Lidiia, D. Sc. in Economics, Professor of the Department of entrepreneurship, management of organizations and logistics,

Zaporizhzhya National University, e-mail: goroshkova69@gmail.com

Volkov Vladimir, D. Sc. in technical, professor, Professor of the Department of entrepreneurship, management of organizations and logistics, Zaporizhzhya National University, e-mail: volkovvp49@gmail.com

Khlobystov levhen, D. Sc. in Economics, professor, Professor of the Department of Environmental Studies, National university of «Kyiv-Mohyla academy», e-mail: ievgen.khlobystov@ukr.net 